\title{
Cellular imaging with structural and mechanical alterations against external stimuli using scanning acoustic microscopy
}

\author{
Katsutoshi Miura ${ }^{1}$ and Yasuko Fukushi ${ }^{2}$ \\ ${ }^{I}$ Department of Health Science, Pathology and Anatomy, Hamamatsu University School of Medicine, Hamamatsu, \\ 431-3192, Japan \\ ${ }^{2}$ Department of Innovative Medical Photonics, Institute for Photonics Research, Preeminent Medical Photonics Education \& \\ Research Center, Hamamatsu University School of Medicine, Hamamatsu, 431-3192, Japan
}

\begin{abstract}
Cells receive external stimuli to incur structural and functional damages. On scanning acoustic microscopy (SAM), speed-of-sound (SOS), attenuation-of-sound (AOS), and thickness values are plotted on the screen to create cellular images, which are related to stiffness, viscosity, and cell size, respectively. The obtained digital data compared using statistical analysis. We aimed to investigate the effects of anticancer drugs, acidic fluids, and heat effects on the cells by using SAM. Anticancer drug cisplatin induced cancer cell apoptosis/necrosis and regeneration in culture, causing elevated SOS, reduced AOS, and thickness. During a more prolonged incubation, the SAM values fluctuated differently between the cisplatin-treated and untreated cells. The tannic and acetic acid and microwave stimuli induced SOS and AOS elevations. These stimuli altered the cell size, number, differentiation, viscosity, and stiffness, which corresponded well to the fluctuation of the SOS and AOS values after incubation. Different anticancer drugs interacted with cancer cells to induce the characteristic alterations of the SAM values. These structural and mechanical alterations induced in cells was difficult to observe on light microscopy. Cellular damages were statistically compared between different stimuli and time-lapse cellular changes were observed using a SAM analysis. SAM is a useful modality to evaluate cellular damage.
\end{abstract}

Keywords: Scanning acoustic microscopy, speed of sound, attenuation of sound, anticancer drugs, tannic acid, acetic acid, microwave, mechanical damage

\section{Introduction}

Cell structures and functions are altered by various environmental factors such as heat, acids, and drugs. Light microscopy (LM) can be used to observe structural changes but has difficulty visualizing mechanical changes. Scanning acoustic microscopy (SAM) (1)(2) can visualize both histological and mechanical alterations, and the digital data it provides are comparable between different situations and stimulus durations (3)(4)(5). To date, we have reported the application of SAM in various states or diseases such as cancer cells (6), lymph nodes (7), lungs (8), thyroids (9), stomach (10), skin wound (11), aorta (12), aortic valve (13), and renal artery (14).

SAM imaging provides speed-of-sound (SOS), attenuation-of-sound (AOS), and section thickness data. SOS corresponds to stiffness, which means stiffer materials covey ultrasound faster. AOS is the energy loss of sound propagation in materials. Thermal consumption of energy caused by viscosity always occurs, which indicates that more-viscous materials have high AOS according to Stokes' law of sound attenuation (15). Therefore, SAM can provide both structural and functional information simultaneously. To date, SAM has been used for examining cell properties such as cell shape (16) and nuclei (17), cellular cycle (18), and intracellular changes (19). However, comparative studies before and after cellular damage using both SMA and LM have been scarcely reported. In this study, we aimed to investigate cellular alteration against external stimuli of anticancer drugs, acid fluids, and microwave heating. SAM proved to be a useful modality for investigating cellular damage.

\section{Results \\ BxPC 3 cell incubation in different cisplatin concentrations}

BxPC3 cells were incubated in $0,50,500$, and $1000 \mu \mathrm{M}$ of cisplatin for $24 \mathrm{~h}$ (Fig. 1). Apoptotic cells, which showed smaller sizes of pyknotic nuclei and eosinophilic cytoplasm than live cells, increased with higher concentrations. The SAM image was altered by the concentration. Cell size gradually decreased according to concentration (Fig. 2). The values of SOS of higher concentration were higher than the value of SOS of lower concentration (Fig. 3A, Table 1). AOS gradually decreased according to the concentration (Fig. 3B). Cellular thickness was gradually reduced with higher concentrations (Fig. 3C). 

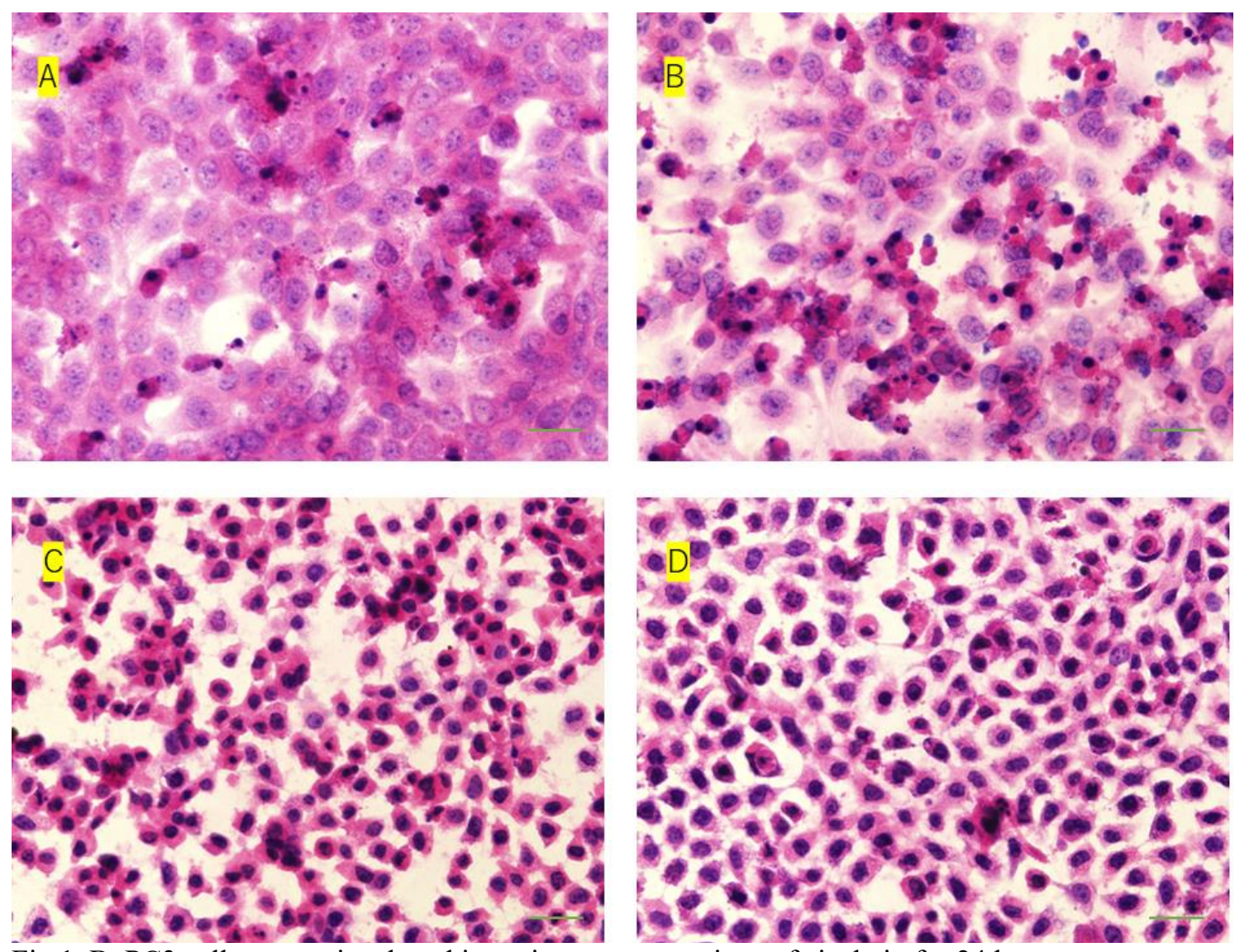

Fig 1. BxPC3 cells were incubated in various concentrations of cisplatin for $24 \mathrm{~h}$.

Numbers of apoptotic cells, which showed pyknotic nuclei and eosinophilic cytoplasm, increased with ascending drug concentration. A; No Cisplatin, B;50 $\mu \mathrm{M}, \mathrm{C} ; 500 \mu \mathrm{M}, \mathrm{D} ; 1000 \mu \mathrm{M}$. The scale bar represents $20 \mu \mathrm{m}$. 


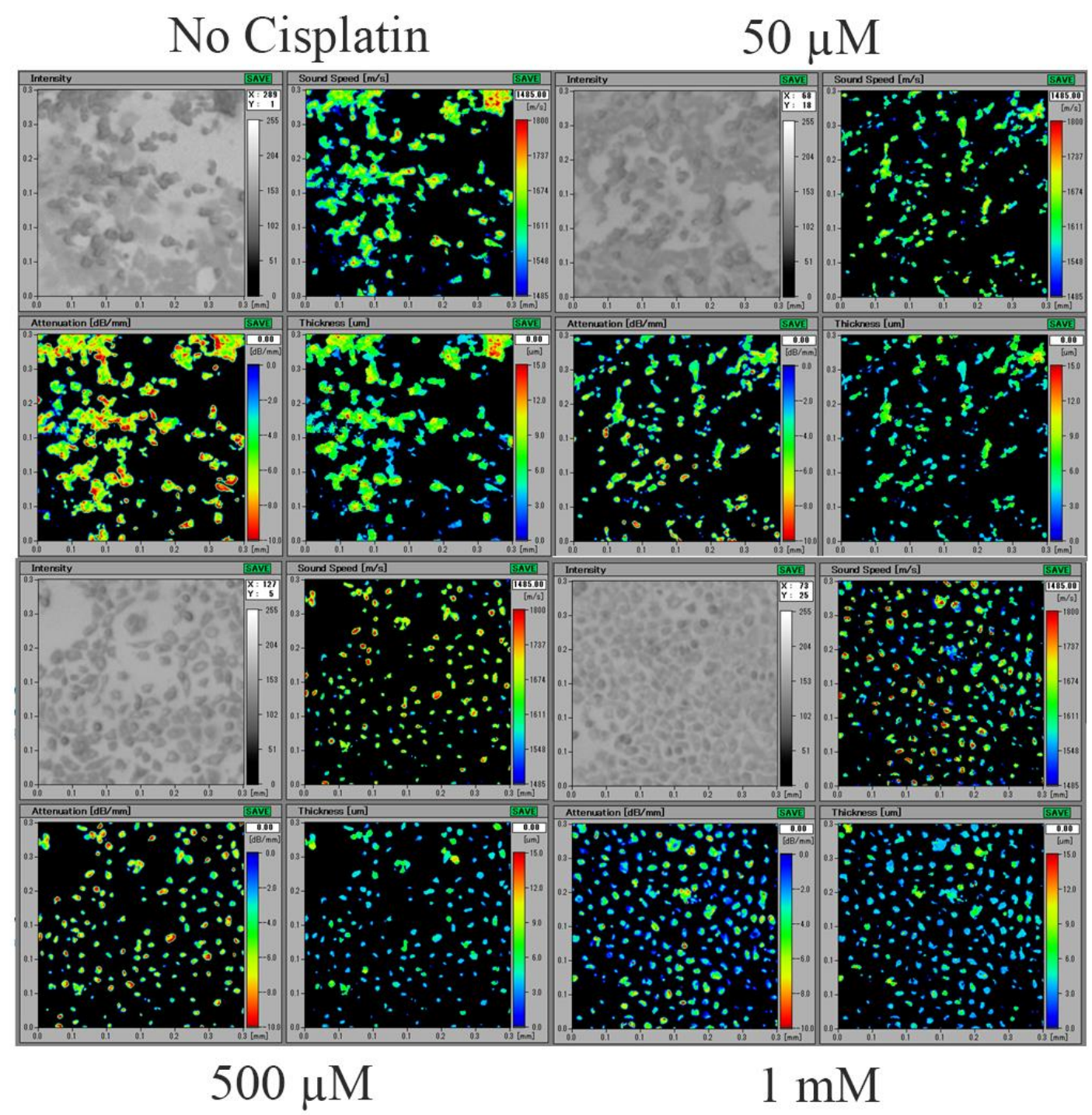

Fig 2. SAM images of cells treated with various concentrations of cisplatin.

SAM images showed concentration-related changes with cell size gradually decreasing with increasing concentration.

Table 1. SAM values after cisplatin treatment

$\begin{array}{lrrrr}\text { SOS m/s }(\mathrm{n}=15) & \text { Control } & 50 \mu \mathrm{M} & 500 \mu \mathrm{M} & 1 \mathrm{mM} \\ \text { average } & 1664.5 & 1650.3 & 1733.4 & 1705.3 \\ \text { SD } & 45.1 & 29.4 & 53.6 & 73.3 \\ & & & & \\ \text { AOS dB/mm(n=15) } & \text { Control } & 50 \mu \mathrm{M} & 500 \mu \mathrm{M} & 1 \mathrm{mM} \\ \text { average } & 5.49 & 4.99 & 5.11 & 3.10 \\ \text { SD } & 1.88 & 1.03 & 1.44 & 1.69\end{array}$

Thickness $\mu \mathrm{m}(\mathrm{n}=15)$

Control $\quad 50 \mu \mathrm{M} \quad 500 \mu \mathrm{M} \quad 1 \mathrm{mM}$

average

9.92

6.41

6.76

4.22

SD

5.18

1.70

2.10

1.09 


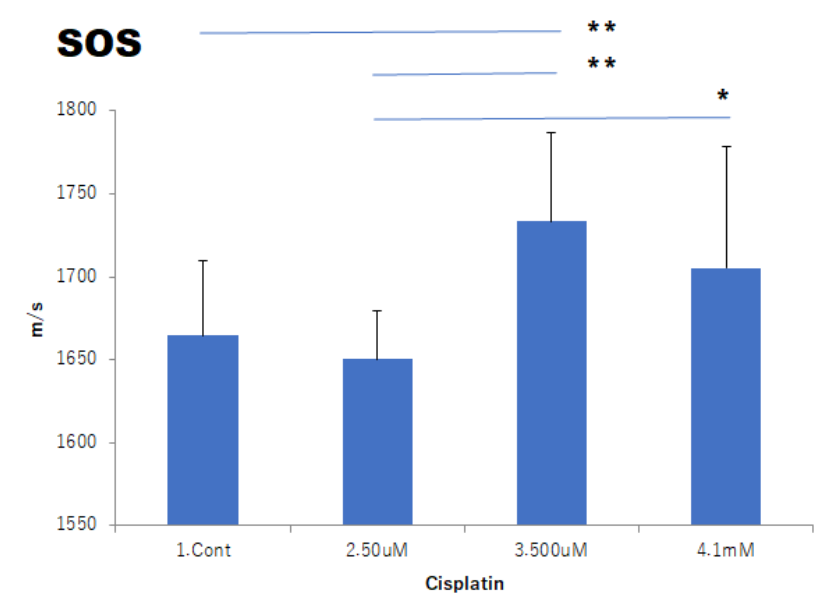

\section{AOS}

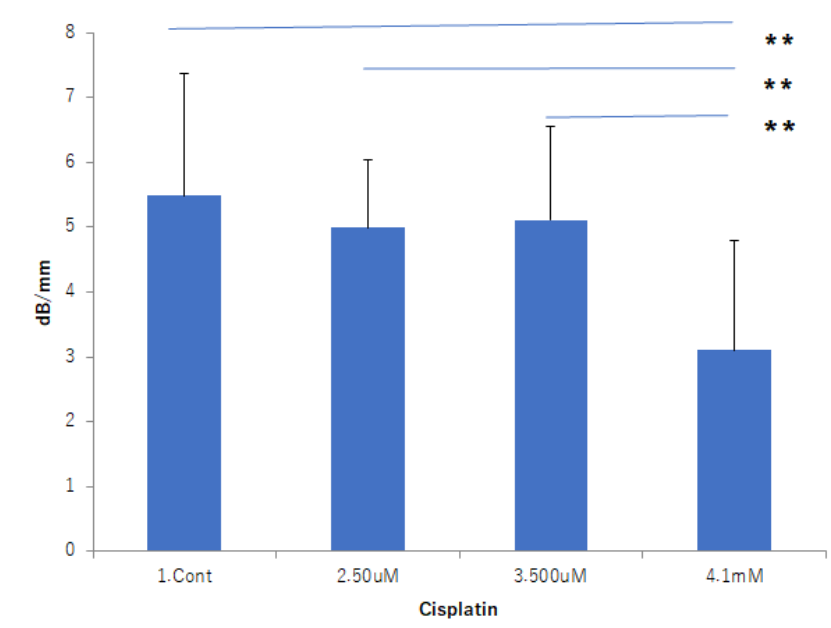

\section{Thickness}

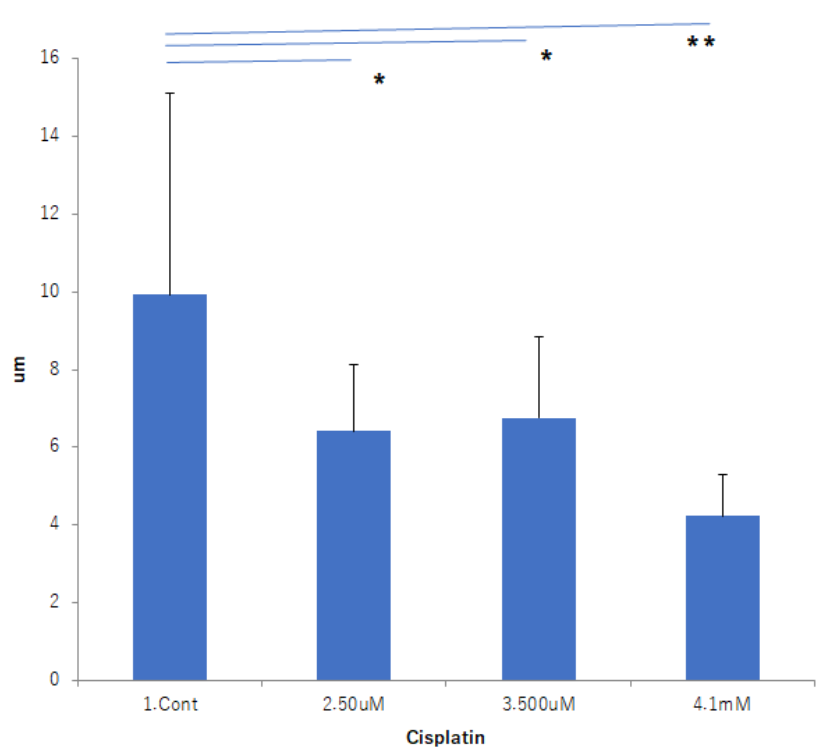

Fig 3. SAM values after treatment with different concentrations of cisplatin. (A)SOS, (B)AOS, (C)Thickness.

SOS of higher concentration displayed higher values compared with those of lower concentration. AOS gradually decreased with increasing concentration. Cell thickness also gradually reduced with increasing concentration. ${ }^{* *} p<0.01,{ }^{*} p<0.05$.

\section{Incubation of BxPC 3 cells in cisplatin for 2 to 5 days}

Fig. 4 shows the apoptosis and necrosis of BxPC3 cells with or without cisplatin. Compared with the control (untreated) cells, the treated cells showed a gradual reduction in the total number of cells with increased apoptosis and necrosis. 
On SAM imaging, the total number of cells gradually decreased according to the duration (Fig. 5). Compared with the untreated cells, the size of the treated cells was also reduced. The SOS and AOS images of the untreated cells on days 4 and 5 disappeared because the cell layers were too thick. Cancer cells piled up to form multiple-layer structures. The SOS of the treated cells increased with duration, whereas that of the untreated cells gradually decreased (Fig. 6A, Table 2). The AOS of the treated cells was variable, and no significant changes were found, whereas the untreated cells showed a marked reduction corresponding to the duration (Fig. 6B). The thickness of the treated cells was significantly reduced from D2 to D3, whereas that of the untreated cells increased gradually from C2 to C5 (Fig. 6C).

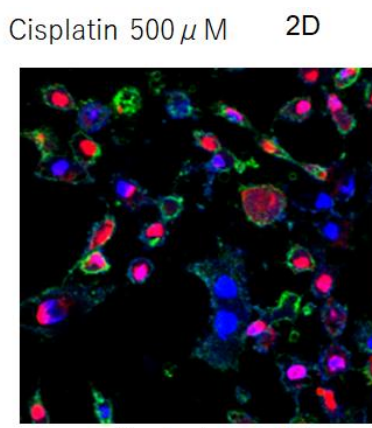

Control

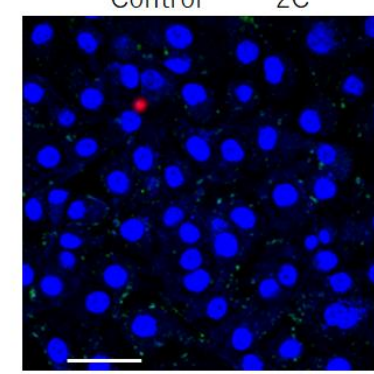

Fig 4. Apoptosis and necrosis in BxPC3 cells treated with cisplatin from day 2 to day 5.

Compared with untreated control cells, treated cells showed a gradual reduction in cell number with enhanced apoptosis and necrosis. Necrosis; red, Apoptosis; green, Nucleus; blue. The scale bar represents $50 \mu \mathrm{m}$. 

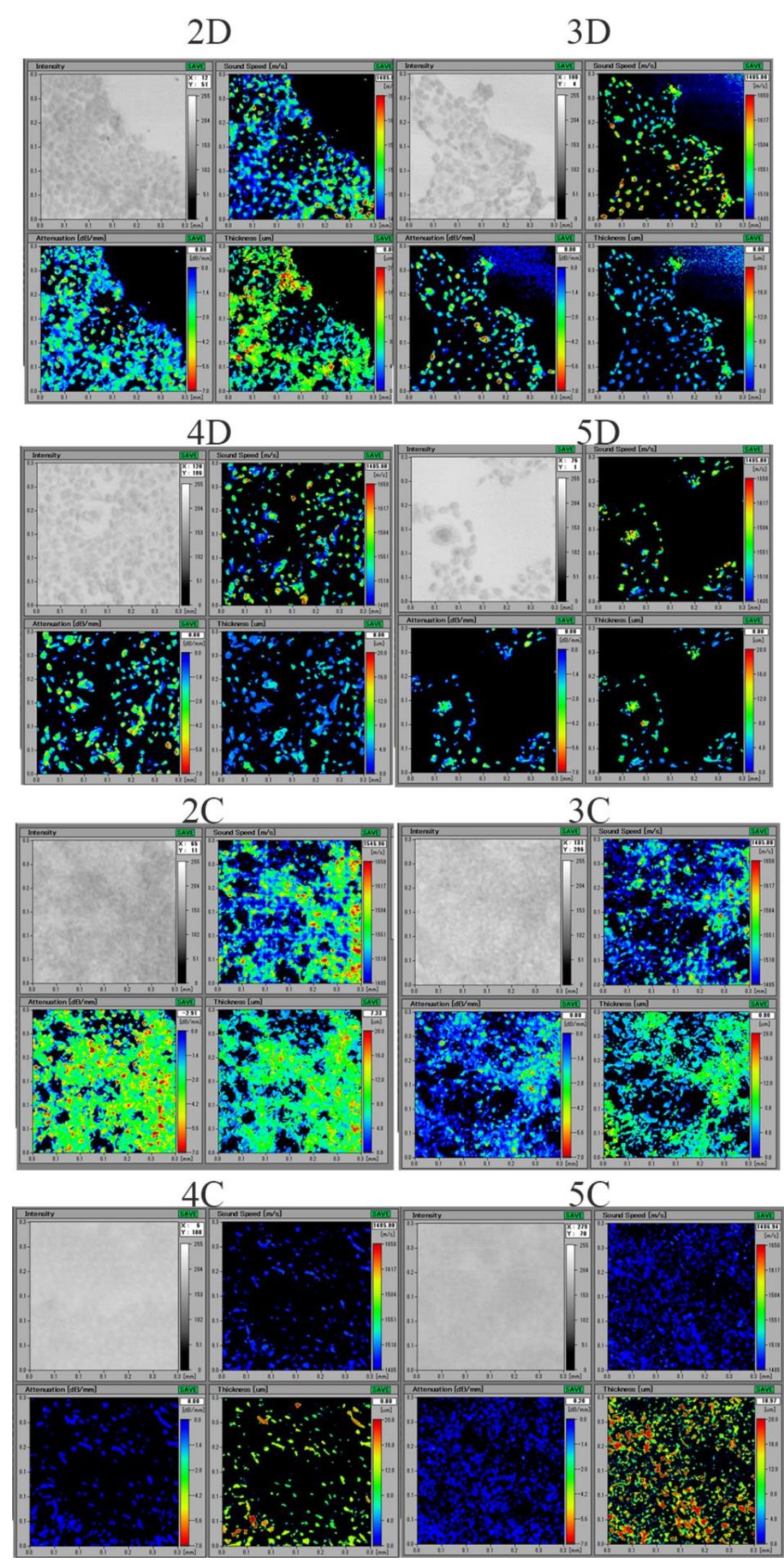

Fig 5. SAM imaging of BxPC3 cells treated with cisplatin from day2 to day5.

The total number of the cells gradually decreased with increasing duration. Compared to untreated cells $(2 \mathrm{C}-5 \mathrm{C})$, the size of the treated cells (2D-5D) was also reduced. 4C and 5C showed no SOS and AOS images due to excess thickness

Table 2. SAM values of cisplatin-treated (2-5D) and untreated cells (C-2D to C-5D) after incubation $\mathrm{SOS}(\mathrm{m} / \mathrm{s})$

n average 


$\begin{array}{lllr}\text { 3D } & 10 & 1586.3 & 40.3 \\ \text { 4D } & 10 & 1586.4 & 43.3 \\ \text { 5D } & 10 & 1578.6 & 23.4 \\ \text { C-2D } & 10 & 1542.6 & 21.3 \\ \text { C-3D } & 10 & 1549.8 & 27.5 \\ \text { C-4D } & 10 & 1503.6 & 9.1 \\ \text { C-5D } & 10 & 1493.3 & 6.2\end{array}$

$\begin{array}{lrrr}\text { AOS }(\mathrm{dB} / \mathrm{mm}) & \mathrm{n} & \text { average } & \text { SD } \\ \text { 2D } & 10 & 2.60 & 1.22 \\ \text { 3D } & 10 & 2.67 & 1.10 \\ \text { 4D } & 10 & 1.96 & 1.33 \\ \text { 5D } & 10 & 2.40 & 0.93 \\ \text { C-2D } & 10 & 3.53 & 0.81 \\ \text { C-3D } & 10 & 2.21 & 0.72 \\ \text { C-4D } & 10 & 0.51 & 0.59 \\ \text { C-5D } & 10 & 0.34 & 0.25\end{array}$

$\begin{array}{lrrr}\text { Thickness } \mu \mathrm{m} & \mathrm{n} & \text { average } & \text { SD } \\ \text { 2D } & 10 & 9.56 & 3.29 \\ \text { 3D } & 10 & 6.33 & 1.86 \\ \text { 4D } & 10 & 7.03 & 1.43 \\ \text { 5D } & 10 & 8.17 & 2.75 \\ \text { C-2D } & 10 & 9.46 & 2.11 \\ \text { C-3D } & 10 & 8.08 & 1.07 \\ \text { C-4D } & 10 & 13.59 & 1.94 \\ \text { C-5D } & 10 & 18.42 & 2.90\end{array}$




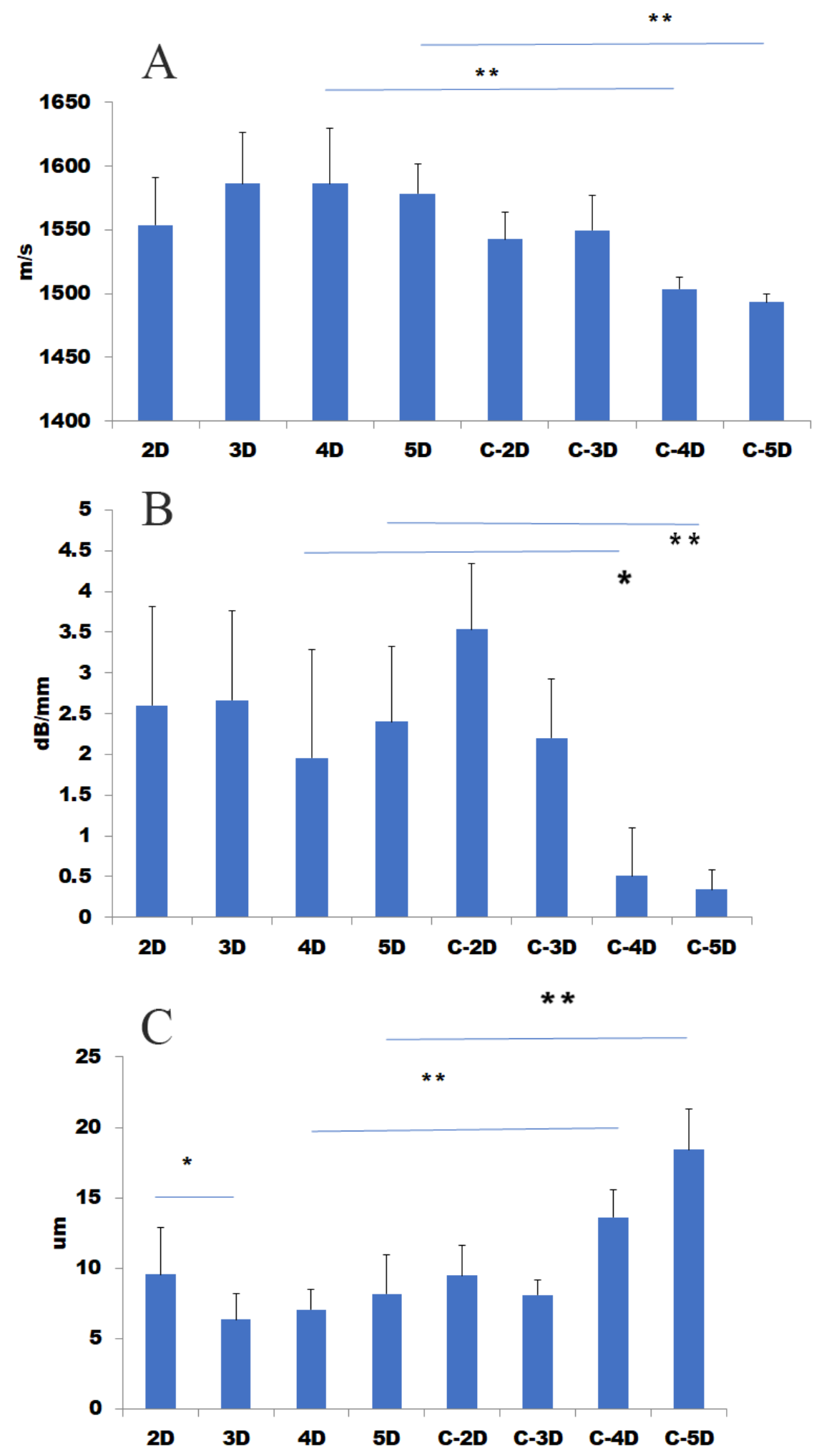

Fig 6. SAM value alterations during incubation. (A)SOS, (B)AOS, (C)thickness.

SOS of the treated cells increased with duration, whereas the same in untreated cells decreased gradually. AOS of treated cells was variable but with no significant changes, whereas untreated cells showed marked reduction depending on duration. Thickness of treated cells significantly reduced from D2 to D3, whereas that of untreated cells increased with longer duration. ${ }^{* *} p<0.01,{ }^{*} p<0.05$.

Ki-67 immunostaining showed proliferating cells (Fig. 7). Although the treated cells at D2 and D3 had no positive cells, 
positive cells appeared at D4 and D5 with some mitosis. The untreated cells at C2 and C3 had a few positive cells and increased in number at $\mathrm{C} 4$ and $\mathrm{C} 5$ with some mitotic figures. Cytokeratin immunostaining indicated a differentiation marker of epithelial features of cancer cells (Fig. 8). The treated cells displayed several positive cells from D2 to D5, whereas the untreated cells showed tiny positive cells at C2 and C3, and that exhibited a remarkable increase of positive cells at C4 and C5. Table 3 summarizes the differences in proliferation characteristics between the cisplatin-treated and untreated cells.

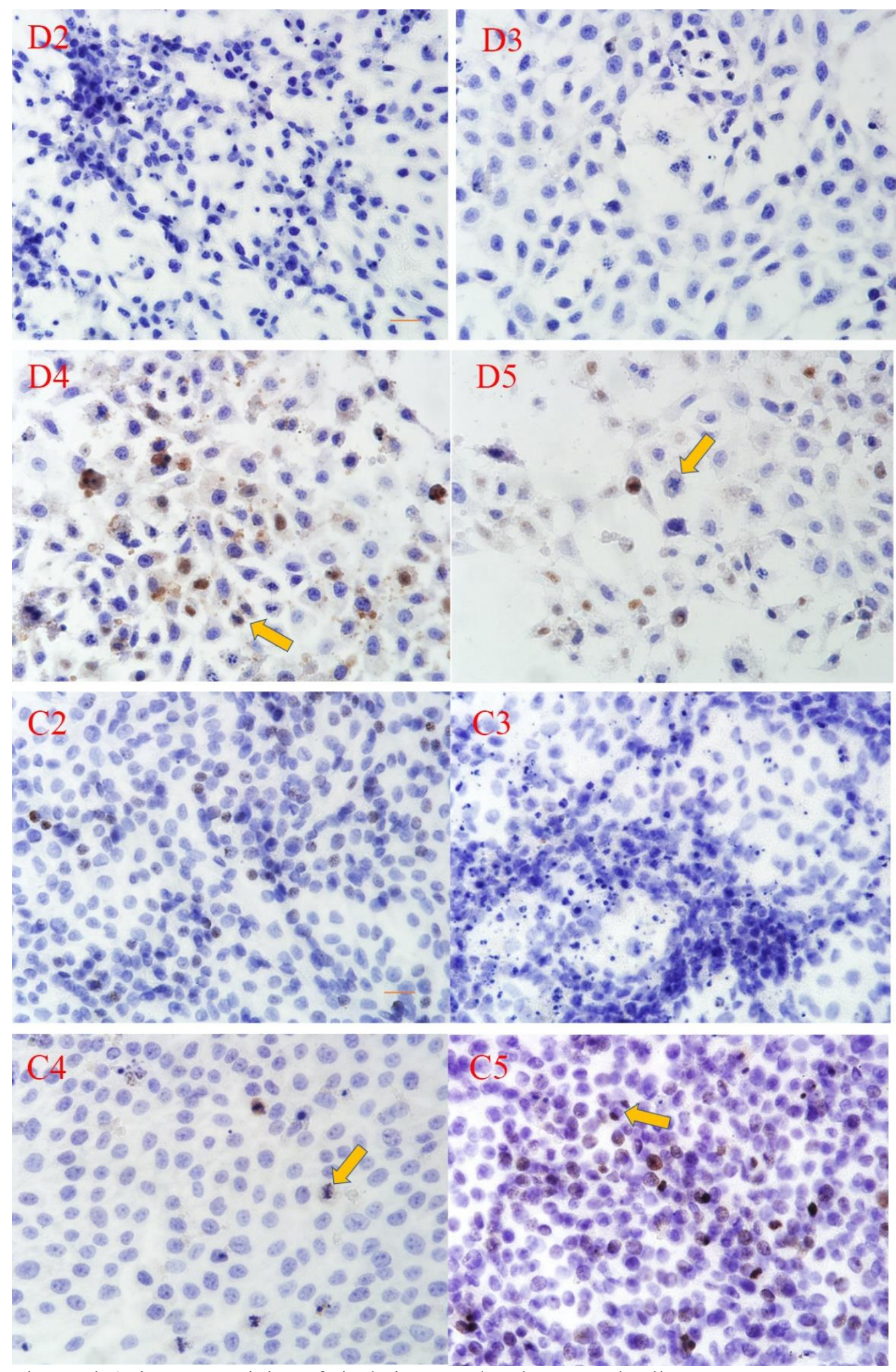

Fig 7. Ki-67 immunostaining of cisplatin treated and untreated cells.

Although the treated case at D2 and D3 showed no positive cells, positive cells appeared at D4 and D5 with some mitosis (arrows). The untreated case had positive cells at C2 and with more positive cells at C4 and C5 and some mitosis. The scale bars represent $20 \mu \mathrm{m}$. 

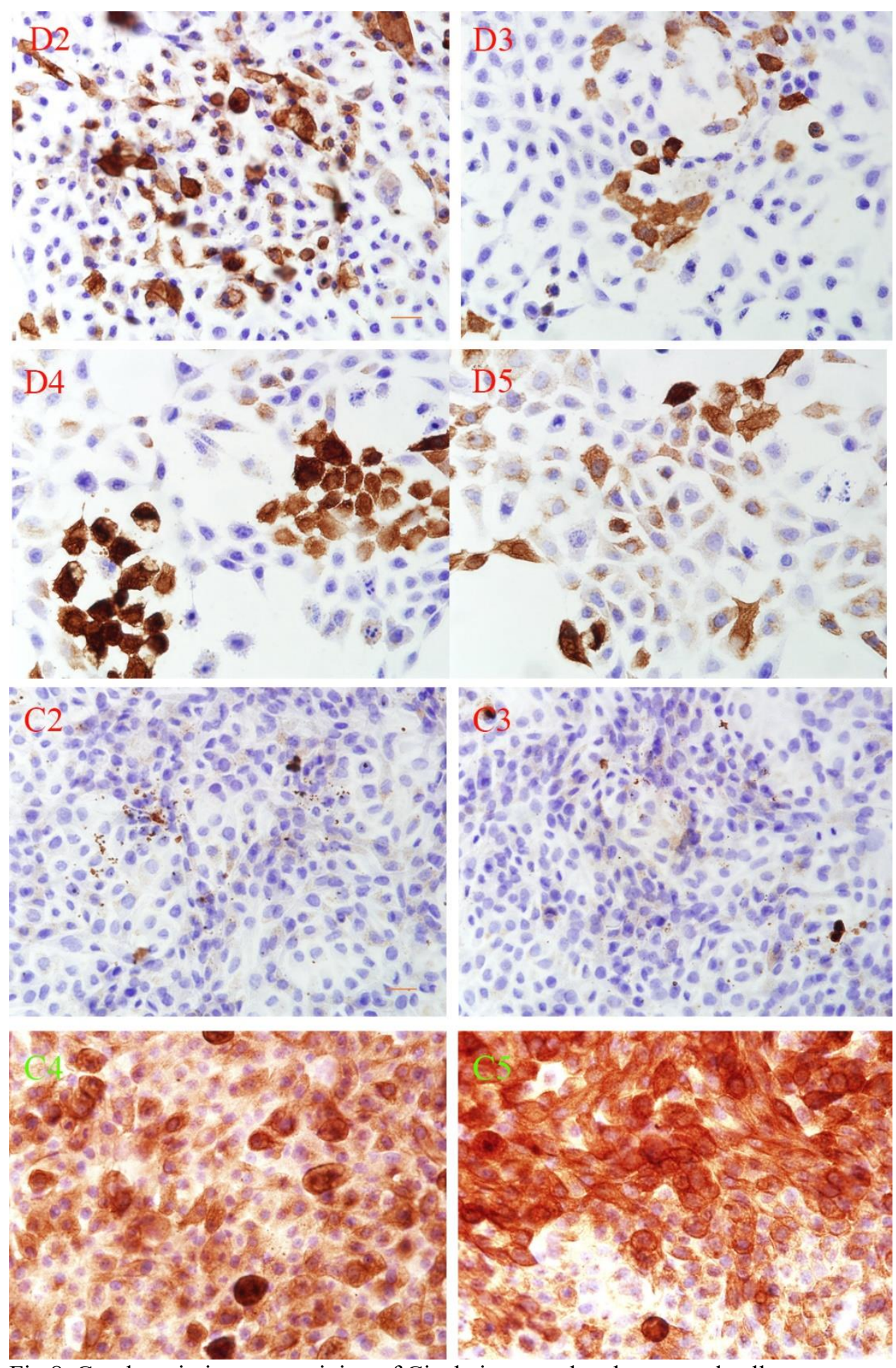

Fig 8. Cytokeratin immunostaining of Cisplatin treated and untreated cells.

Treated cells displayed several positive cells from D2 to D5, whereas untreated cells showed tiny positive cells at C2 and $\mathrm{C} 3$ and exhibited remarkable positive cells at C4 and C5. The scale bars represent $20 \mu \mathrm{m}$.

Table 3. Differences in proliferation characteristics between cisplatin-treated and untreated cells

$\begin{array}{lllll}\text { Cisplatin } & \text { D2 } & \text { D3 } & \text { D4 } & \text { D5 } \\ \text { cellularity } & + & + & \text { low } & \text { lower } \\ \text { apoptosis } & - & + & - & - \\ \text { Ki67/mitosis } & - & - & + & + \\ \text { CK } & \text { +focal } & \text { +focal } & \text { +focal } & \text { +focal }\end{array}$




$\begin{array}{lllll}\text { Control } & \mathrm{C} 2 & \mathrm{C} 3 & \mathrm{C} 4 & \mathrm{C} 5 \\ \text { cellularity } & ++ & ++ & +++ & +++ \\ \text { apoptosis } & - & ++ & - & + \\ \text { Ki67/mitosis } & + & \text { very few } & + & ++ \\ \text { CK } & \text { a few } & \text { a few } & ++ & +++\end{array}$

\section{Cancer cells incubated in different anticancer drugs}

Adenocarcinoma cells fixed in $95 \%$ ethanol on glass slides were soaked in the anticancer drugs solution at $20^{\circ} \mathrm{C}$. Fig. 9 shows images of the fluctuation of the SAM values after incubation. Actinomycin D and oxaliplatin gradually increased the SOS and AOS values. On the contrary, cisplatin and carboplatin decreased these values after incubation (Fig. 10, Table 4). The thickness was stable within $1.5 \mathrm{~mm}$ fluctuation. To examine the location of cisplatin in the cell, we used the EPMA method. The platinum was gathered on the cancer nuclei (Figure S1). 

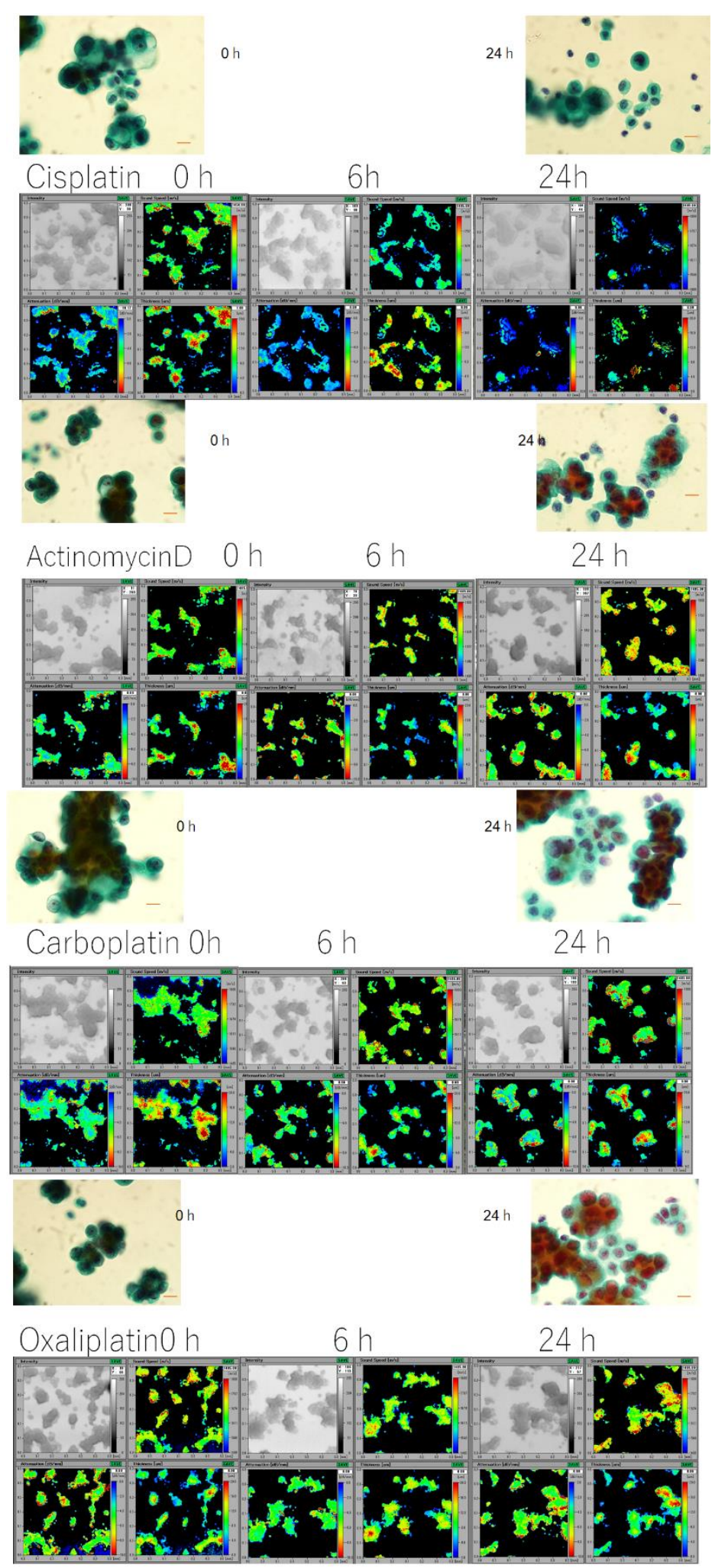

Fig 9. SAM images of adenocarcinoma cells soaked in various anticancer drugs.

SAM images were followed at $6 \mathrm{~h}$ intervals up to $24 \mathrm{~h}$. The corresponding LM image with Papanicolaou stain, before and at $24 \mathrm{~h}$ after incubation. The scale bars represent $500 \mu \mathrm{m}$. 

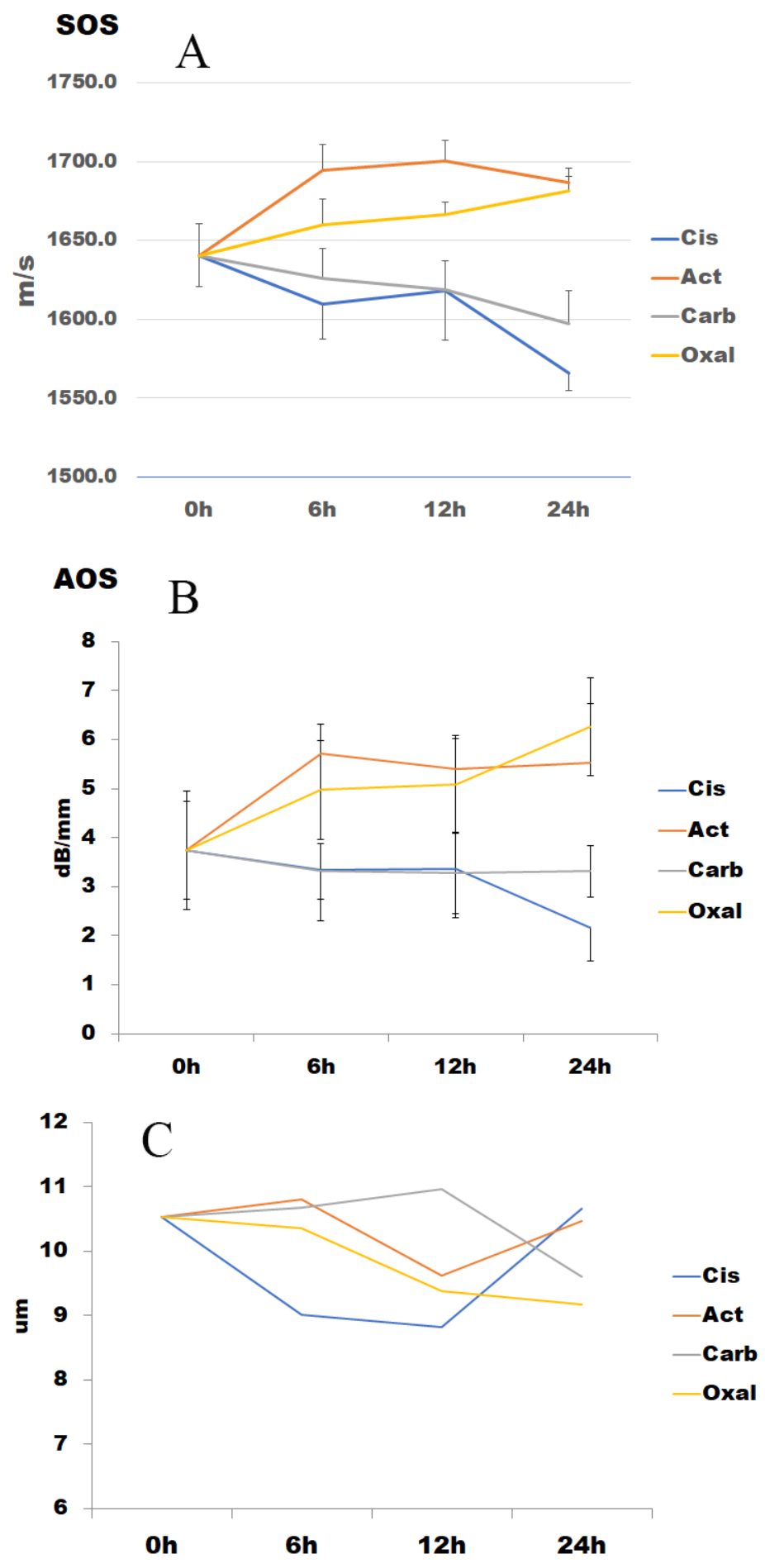

Fig 10. Alterations in SAM values of different anticancer drugs after incubation. (A)SOS, (B) AOS, (C) Thickness. Each drug showed a different course after incubation. Cis; Cisplatin, Act; Actinomycin D, Carb; Carboplatin, Oxal; Oxaliplatin.

Table 4. Changes in SAM values after incubation with anticancer drugs.

$\begin{array}{lrrrrrrrr}\text { SOS m/s } & \text { ave0h } & 6 \mathrm{~h} & 12 \mathrm{~h} & 24 \mathrm{~h} & \text { SD 0h } & 6 \mathrm{~h} & 12 \mathrm{~h} & 24 \mathrm{~h} \\ \text { Cisplatin } & 1640.3 & 1609.4 & 1617.7 & 1565.5 & 19.90 & 21.83 & 31.04 & 10.70 \\ \text { Act } & 1640.3 & 1694.7 & 1700.4 & 1686.4 & 19.90 & 16.28 & 13.22 & 4.13 \\ \text { Carb } & 1640.3 & 1625.6 & 1618.4 & 1597.1 & 19.90 & 19.34 & 18.80 & 20.66\end{array}$




$\begin{array}{lrrrrrrrr}\text { Oxalis } & 1640.3 & 1659.5 & 1666.3 & 1681.2 & 19.90 & 16.56 & 7.88 & 14.35 \\ & & & & & & & & \\ \text { AOS dB/mm } & \text { ave0h } & 6 \mathrm{~h} & 12 \mathrm{~h} & 24 \mathrm{~h} & \text { SD 0h } & 6 \mathrm{~h} & 12 \mathrm{~h} & 24 \mathrm{~h} \\ \text { Cis } & 3.74 & 3.35 & 3.36 & 2.18 & 1.21 & 1.05 & 0.99 & 0.70 \\ \text { Act } & 3.74 & 5.72 & 5.39 & 5.52 & 1.21 & 0.61 & 0.63 & 1.21 \\ \text { Carb } & 3.74 & 3.32 & 3.29 & 3.32 & 1.21 & 0.56 & 0.83 & 0.53 \\ \text { Oxal } & 3.74 & 4.97 & 5.09 & 6.27 & 1.21 & 1.00 & 1.18 & 1.42 \\ & & & & & & & & \\ \text { Thick } \mu \mathrm{m} & \text { ave0h } & 6 \mathrm{~h} & 12 \mathrm{~h} & 24 \mathrm{~h} & \mathrm{SD} 0 \mathrm{~h} & 6 \mathrm{~h} & 12 \mathrm{~h} & 24 \mathrm{~h} \\ \text { Cis } & 10.53 & 9.02 & 8.82 & 10.66 & 2.77 & 1.87 & 2.08 & 1.94 \\ \text { Act } & 10.53 & 10.80 & 9.63 & 10.46 & 2.77 & 3.10 & 3.15 & 2.22 \\ \text { Carb } & 10.53 & 10.68 & 10.97 & 9.61 & 2.77 & 1.25 & 2.01 & 1.75 \\ \text { Oxal } & 10.53 & 10.36 & 9.38 & 9.18 & 2.77 & 2.17 & 1.88 & 1.42\end{array}$

Cis; Cisplatin, Act; Actinomycin D, Carb; Carboplatin, Oxal; Oxaliplatin.

\section{Cancer cells in tannic acid and acetic acid treatment}

According to the concentration, ovarian adenocarcinoma cells in tannic acid displayed gradual alteration of SAM images (Fig. 11). SOS and AOS increased with higher concentrations, while the thickness was gradually reduced (Fig. 12, Table 5). The light microscopic image showed a three-dimensional to a flat image after treatment.

With acetic acid, the SOS and AOS values increased in proportion to the concentration, and the thickness gradually decreased with a higher concentration (Figures S2 and S3, Table S1). 


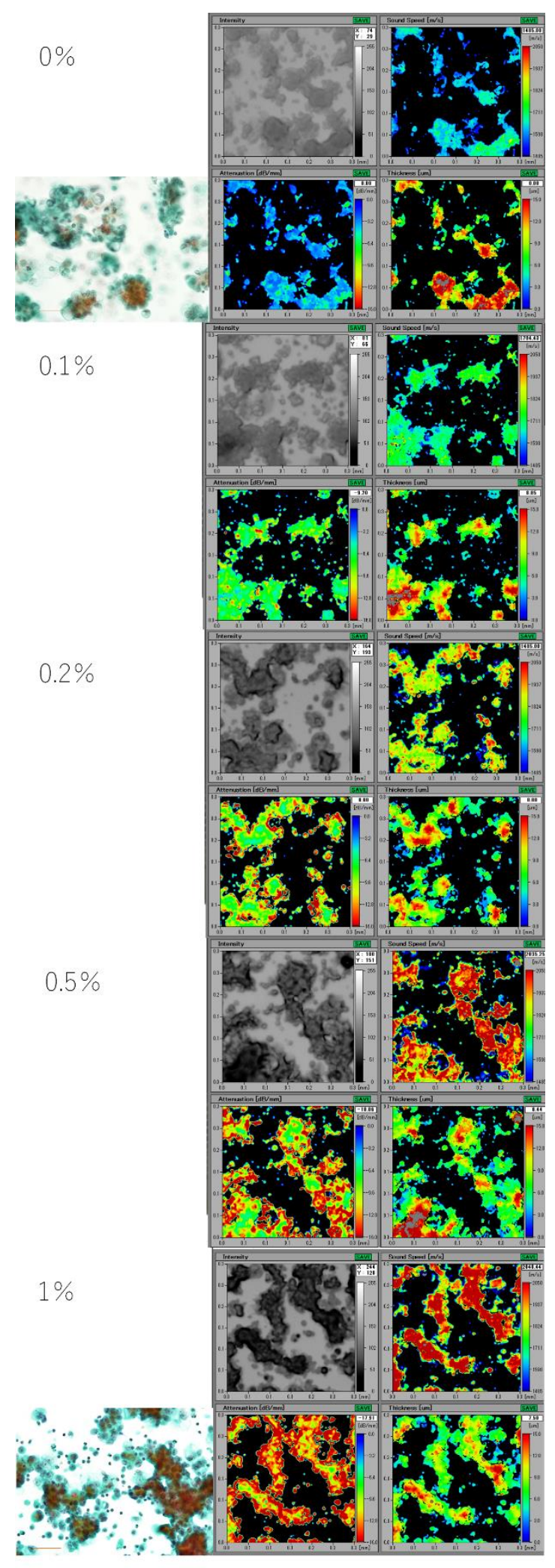

Fig 11. SAM images of ovarian adenocarcinoma cells incubated in different concentrations of tannic acid. SOS and AOS increased with higher concentration, while thickness gradually reduced.

The corresponding LM image in the Papanicolaou stain showed a three-dimensional to a flat image after $1 \%$ tannic acid incubation. The scale bars represent $40 \mu \mathrm{m}$. 

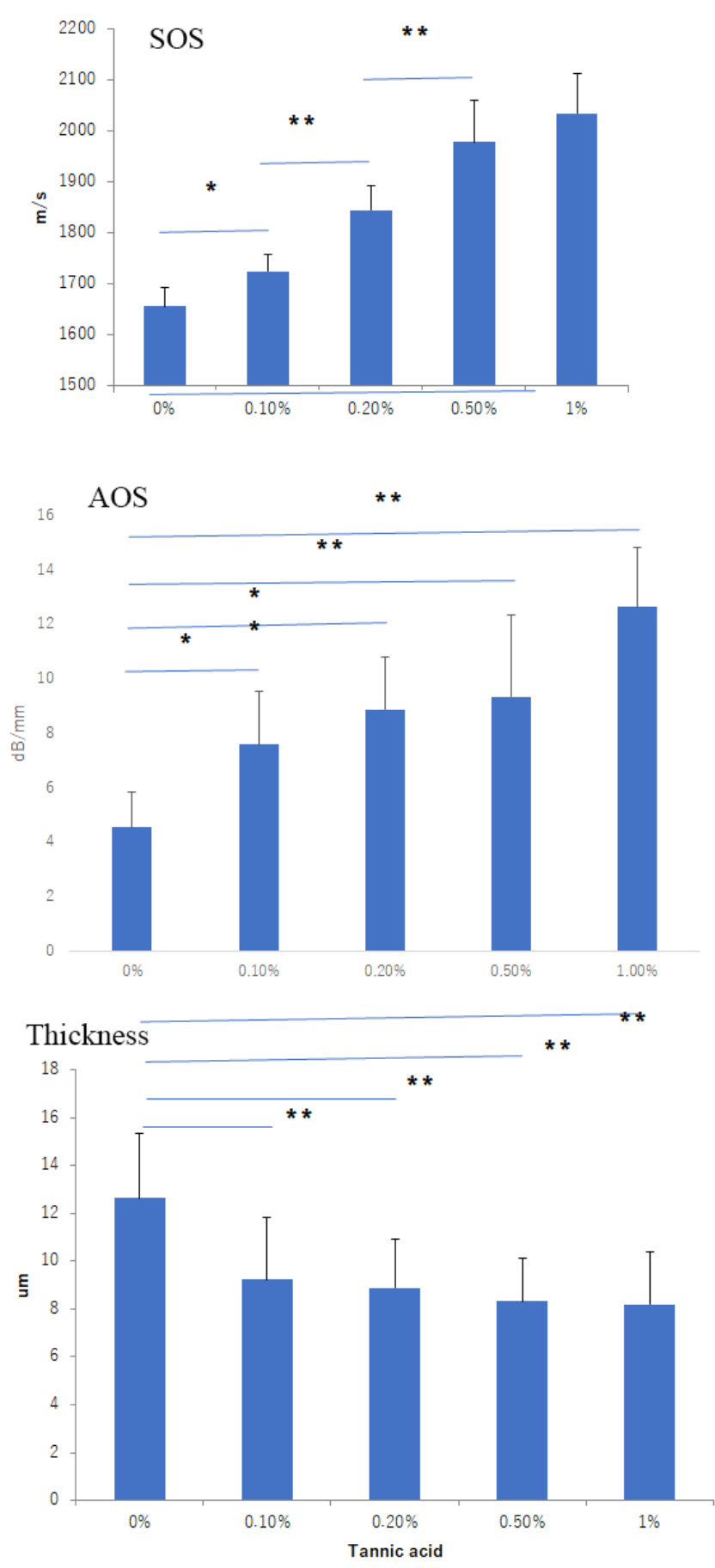

Fig 12. SMA value alteration among different concentrations of tannic acid.

SOS and AOS increased according to higher concentration, while thickness gradually reduced. ${ }^{*} p<0.01,{ }^{*} p<0.05$.

Table 5. Changes in SAM values after tannic acid incubation

AOS SD Thick SD

$\begin{array}{rrrrrrr}0 \% & 1655.8 & 4.54 & 12.64 & 37.61 & 1.30 & 2.73 \\ 0.10 \% & 1724.3 & 7.58 & 9.25 & 33.96 & 1.95 & 2.57\end{array}$




$\begin{array}{llrllll}0.20 \% & 1844.7 & 8.88 & 8.88 & 48.77 & 1.90 & 2.04 \\ 0.50 \% & 1978.8 & 9.33 & 8.32 & 80.26 & 3.04 & 1.81 \\ 1.00 \% & 2034.5 & 12.64 & 8.19 & 76.96 & 2.19 & 2.22\end{array}$

\section{Adenocarcinoma in microwave treatment}

Microwave was irradiated to fixed ovarian adenocarcinoma cells in water. The temperature of water increased from $14.8^{\circ} \mathrm{C}$ to $22.8^{\circ} \mathrm{C}$ during incubation for $10 \mathrm{sec}$. The SAM images were altered by the duration of the irradiation (Fig. 13). SOS and AOS gradually increased according to the duration, while the thickness showed no significant changes (Fig. 14, Table 6). The corresponding LM image displayed three-dimensional to flat images after microwave treatment. 


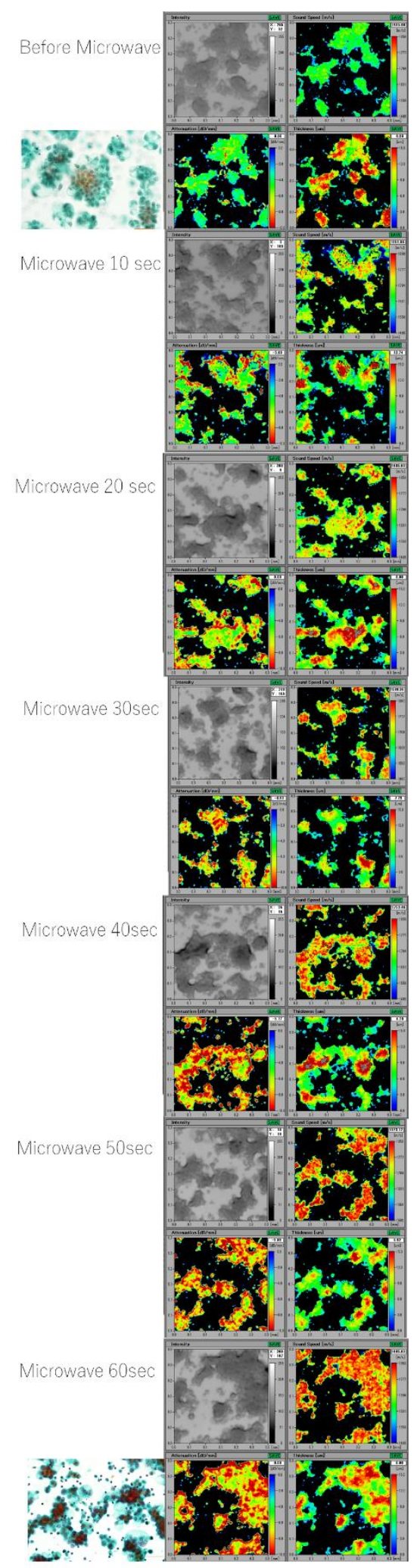

Fig 13. SAM images of ovarian adenocarcinoma cells after microwave irradiation.

SOS and AOS increased according to more extended irradiation, while thickness displayed no remarkable changes. The corresponding LM image in the Papanicolaou stain showed no conspicuous changes. The scale bars represent $40 \mu \mathrm{m}$ 

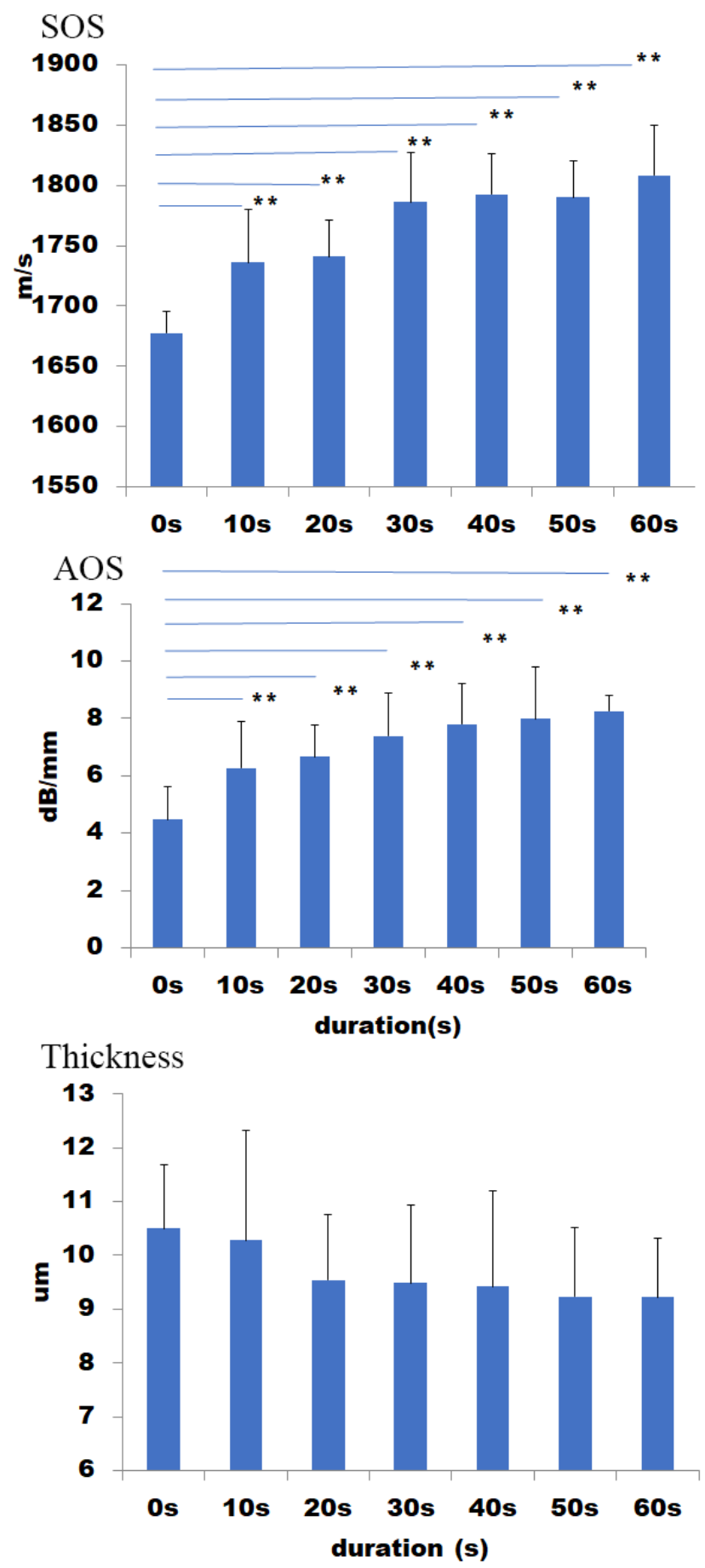

Fig 14. SAM value alteration after microwave irradiation.

The SOS and the AOS significantly increased according to longer duration, whereas the thickness showed no significant changes. $\quad * * p<0.01, * p<0.05$.

Table 6. Changes in SAM values after microwave irradiation.

$\begin{array}{lrrrrrrr}\text { SOS m/s } & 0 & 10 \mathrm{~s} & 20 \mathrm{~s} & 30 \mathrm{~s} & 40 \mathrm{~s} & 50 \mathrm{~s} & 60 \mathrm{~s} \\ \text { Ave } & 1677.4 & 1736.1 & 1741.1 & 1786.5 & 1792.5 & 1790.4 & 1808.5 \\ \text { SD } & 18.3 & 44.1 & 29.9 & 40.5 & 34.0 & 30.1 & 41.4\end{array}$




$\begin{array}{lrrrrrrr}\text { AOS dB/mm } & 0 & 10 \mathrm{~s} & 20 \mathrm{~s} & 30 \mathrm{~s} & 40 \mathrm{~s} & 50 \mathrm{~s} & 60 \mathrm{~s} \\ \text { Ave } & 4.47 & 6.26 & 6.65 & 7.38 & 7.81 & 7.98 & 8.25 \\ \text { SD } & 1.16 & 1.65 & 1.10 & 1.51 & 1.41 & 1.80 & 0.56 \\ & & & & & & & \\ \text { Thick } \mu \mathrm{m} & 0 & 10 \mathrm{~s} & 20 \mathrm{~s} & 30 \mathrm{~s} & 40 \mathrm{~s} & 50 \mathrm{~s} & 60 \mathrm{~s} \\ \text { Ave } & 10.50 & 10.28 & 9.55 & 9.48 & 9.42 & 9.23 & 9.22 \\ \text { SD } & 1.17 & 2.05 & 1.22 & 1.45 & 1.79 & 1.29 & 1.09\end{array}$

\section{Discussion}

In this study, we observed cellular damages due to external stimuli by SAM and LM. Compared with the LM images, the SAM images reacted well to each stimulus and displayed characteristic images.

Cisplatin administration induced cellular damage to apoptosis and necrosis. The degree of damage correlated with the concentration. The SMA images corresponded well to the LM images in cell size and shape. After incubation in anticancer drugs, observation of apoptotic cells has been reported by Strohm et al. (23). They used cultured breast cancer cells (MCF-7), paclitaxel anticancer drugs, and incubated the cells for 15 to $20 \mathrm{~h}$. The apoptotic cells showed greater thickness $(17.3 \pm 1.6 \mu \mathrm{m})$ and $\operatorname{AOS}(65.3 \pm 13.5 \mathrm{~dB} / \mathrm{mm})$, and slightly lower SOS $(1574 \pm 19 \mathrm{~m} / \mathrm{s})$ than the non-apoptotic cells $(13.6$ $\pm 3.1 \mu \mathrm{m}, 40.5 \pm 7.9 \mathrm{~dB} / \mathrm{mm}$, and $1582 \pm 19 \mathrm{~m} / \mathrm{s}$, respectively). The discrepancy of our results that apoptotic cells had reduced thickness and increased AOS and SOS may depend on the observation procedure. They observed living cells in a three-dimensional state in the medium, whereas we examined fixed cells on glass slides. The cells shrank after apoptosis, so the cell thickness must have decreased.

In longer-term incubation in cisplatin for 2 to 5 days, cancer cells first decreased in number and size up to 3 days. Then, regeneration occurred afterward, proved by the appearance of Ki67-positive cells. SOS, AOS, and thickness values peaked at day 2 or 3 and then decreased afterward. Untreated cancer cells showed a gradual increase in number, forming multilayer sheet structures. SAM observation became difficult because no ultrasound could return to the transducer owing to the loss of energy as seen in the images at days 4 (C4) and 5 (C5). Regarding cell maturation, drug-treated cells always showed focal CK markers, whereas untreated cells at the confluent state repressed CK up to day 3 , and then CK antigens remarkably surged. The contact inhibition may suppress cellular differentiation, and after lightening the restriction, cells freely formed a three-dimensional structure with the appearance of CK differentiation markers.

Anticancer drugs of low molecular weight penetrated the cell membrane and bound DNA or proteins. Cisplatin (MW 300), carboplatin (MW 371.2), and oxaliplatin (MW 397.3) are a platinum-based antineoplastic family of medications (24). They cause crosslinking of DNA as monoadduct, interstrand crosslinks, intrastrand crosslinks, or DNA protein crosslinks. Each anticancer drug may have a characteristic distribution to induce conformational changes, which cause different alterations of SOS and AOS values. In contrast to cisplatin and carboplatin, oxaliplatin features the bidentate ligand 1,2-diaminocyclohexane in place of the two monodentate ammine ligands (25). This conformational difference probably caused a reverse course of the SAM value changes between cisplatin/carboplatin and oxaliplatin. Actinomycin D has higher MW 1255.4 than other platinum-based anticancer drugs and binds DNA to inhibit transcription. Although observation of the structural changes induced by these drugs on the usual LM imaging was challenging, SAM was susceptible to identify these alterations on the basis of AOS and SOS values.

Acidic treatment caused cellular degeneration, especially protein aggregation (26). Both tannic and acetic acids increased the SOS and AOS values and decreased the thickness according to increasing concentration. SAM can statistically evaluate the cellular damage induced by acid fluid. Tannic acid is a class of astringent and polyphenolic biomolecules that bind to and precipitate proteins and various other organic compounds, including amino acids and alkaloids(27).

Microwave has thermal and specific microwave effects. In our experiment, the cell temperature increased from $17.2^{\circ} \mathrm{C}$ to $40^{\circ} \mathrm{C}$ at a maximum for $10 \mathrm{sec}$. The heating effects induced protein aggregation in the same way as the acid (26). Hyperthermia is used for anticancer therapy (28). SAM is available for evaluating cell heating damage precisely.

This method of SAM has several limitations that should be acknowledged. First, the fixation effects may influence the SOS values. Ethanol dissolves the membrane lipid bilayer and denatures the proteins (29). Compared with unfixed cells, fixed cells showed higher SOS and lower AOS and thickness values (23)(17). Data corresponded to the alterations of cell proper- 
ties such as increased stiffness, reduced viscosity, and thinner shape after fixation. Second, observation restriction is present. The observable area is $4.8 \mathrm{~mm}^{2}$ in maximum due to the limitation of our instrument scanning area. The thickness of the cell or cell cluster was approximately $10 \mu \mathrm{m}$ because no sound can return because of loss of energy from too-thick materials. The trapping of two waves from too-thin materials is unable to discriminate. Irregular-surfaced materials such as pileup cells are difficult to measure because of reflection and refraction. As a standard value of SOS, an empty area without cells is necessary for measurement at the least one corner, where the SOS value is $1495 \mathrm{~m} / \mathrm{s}$ through water at $25^{\circ} \mathrm{C}$.

\section{Conclusion}

SAM observation can reveal not only histological but also mechanical cell alterations. Moreover, statistical analysis is available for different stimuli and time courses. Both live and fixed cells are available for studying alterations caused by external stimuli.

\section{Materials and Methods \\ Cell observation method with SMA}

The cells were observed with SAM (AMS-50SI, Honda Electronics, Toyohashi, Aichi, Japan) equipped with a 320-MHz transducer (20). The BD CytoRich (Franklin Lakes, NJ, USA) protocol was used for preparing single cell-layer slides for clinical samples (6). Cells were fixed in $95 \%$ ethanol or BD CytoRich preservative for 10 min and kept dry until observation. The cells were resoaked in distilled water before observation.

\section{Cell observation using a confocal microscope system}

Cells were stained with an apoptotic/necrotic/health cell detection kit (PromoCell GmbH, Heidelberg, Germany) containing FITC-Annexin V, Ethidium Homodimer III (EthD-III), and Hoechst 33342. Then, the cells were imaged on confocal microscopy ( $\times 40$ objective) using the Olympus FV1000 confocal microscope system (Olympus, Tokyo, Japan).

\section{BxPC3 cell culture}

BxPC3 (human pancreatic cancer cell line) was received from Dr. K. Shimizu(21). The cells were plated on polystyrene dishes and maintained in DMEM (Thermo Fisher Scientific, Waltham, MA) containing 10\% fetal bovine serum and 100 units $/ \mathrm{mL}$ penicillin $/ 400 \mu \mathrm{g} / \mathrm{mL}$ streptomycin (Thermo Fisher Scientific) at $37^{\circ} \mathrm{C}$ under $5 \% \mathrm{CO}_{2}$.

\section{Anticancer drugs}

Cisplatin, actinomycin D (Fujifilm Wako, Osaka, Japan), carboplatin, oxaliplatin (Tokyo Chemical, Tokyo, Japan) were used as anticancer drugs. All drugs were dissolved in distilled water to obtain requisite final concentration.

\section{BXPC3 cells incubation in various concentrations of cisplatin}

BxPC3 cells were incubated with $0,50,500,1000 \mu \mathrm{M}$ of cisplatin for $24 \mathrm{~h}$ and fixed in $95 \%$ ethanol for SAM or LM analysis.

\section{Incubation of BXPC3 cells in cisplatin for a longer duration ( 2 days to 5 days)}

BxPC3 cells were incubated in $500 \mu \mathrm{M}$ cisplatin for 2 to 5 days (treated group; designated 2D to 5D) or left untreated for the same duration (untreated group; designated $\mathrm{C} 2$ to $\mathrm{C} 5$ ) as control. Cells were retrieved and fixed every day and analyzed by SAM, FM, or LM. Anti-Ki67 and anti-cytokeratin staining was used to identify cell proliferation and epithelial differentiation, respectively.

\section{Cancer cells treated with anticancer drugs}

Lung adenocarcinoma cells in pleural fluid were fixed in $95 \%$ ethanol for $10 \mathrm{~min}$ at $20^{\circ} \mathrm{C}$ on a glass slide and soaked in distilled water. SAM images were initially acquired before incubation. Cells were then treated with anticancer drugs dissolved in water for $6 \mathrm{~h}, 12 \mathrm{~h}$, and $24 \mathrm{~h}$ at $20^{\circ} \mathrm{C}$. Slides were scanned at all timepoints to obtain SAM images.

\section{Platinum distribution detection by Electron Probe Micro Analyzer (EPMA)}

Cisplatin distribution in treated cancer cells was evaluated by scanning electron microscopy JCM-6000 (JEOL, Tokyo, Japan) with $\operatorname{EPMA}(22)$ wherein platinum distribution corresponds to cisplatin distribution.

\section{Tannic acid and acetic acid treatment of cancer cells}

Ovarian adenocarcinoma cells in ascites were fixed in $95 \%$ ethanol for $10 \mathrm{~min}$ at $20^{\circ} \mathrm{C}$ on a glass slide and incubated with tannic acid at concentrations of $0 \%, 0.1 \%, 0.2 \%, 0.5 \%$, and $1 \%$ (in water) for $10 \mathrm{~min}$ at $20^{\circ} \mathrm{C}$. These fixed cells were also incubated in acetic acid at concentrations of $0 \%, 1 \%, 5 \%, 10 \%, 20 \%$, and $40 \%$ for 10 min at $20^{\circ} \mathrm{C}$. SAM and LM images after incubation were compared among the various concentrations. 


\section{Adenocarcinoma in microwave treatment}

Ovarian cancer cells in fluid were fixed in $95 \%$ ethanol for 10 min on a glass slide. After washing in water, the glass slide was dipped in $50 \mathrm{ml}$ of distilled water in a plastic jar and microwaved at $700 \mathrm{~W}$ for 10 seconds, for a total of $60 \mathrm{sec}$. For SAM observation, the same slide was repeatedly scanned from $10 \mathrm{sec}$ to $60 \mathrm{sec}$ at intervals of $10 \mathrm{sec}$.

\section{Immunostaining}

Immunostaining of cells on glass slides was performed using a commercially available Chemmate Envision kit (Dako, Glostrup, Denmark). The primary antibodies used were Ki67 (Dako) and cytokeratin (CK) AE1/3 (Dako) for detecting proliferating cells and epithelial differentiation, respectively. 


\section{Supplementary Materials}

The following are available online. Figure S1: Platinum distribution by Electron Probe Micro Analyzer (EPMA). Figure S2: SAM images of ovarian adenocarcinoma cells incubated with varying concentrations of acetic acid. Table S1: SAM value alterations after acetic acid treatment.

\section{Funding}

This study is supported by Tokai Foundation for Technology, Japan (no. 4 on Mar 4, 2020).

\section{Acknowledgments}

The authors thank Dr. K.Shimizu for providing BXPC3 cells, T. Moriki, Y. Egawa, Y. Kawabata, and N. Suzuki for their assistance in preparing the histological samples, Dr. K. Kobayashi (Honda Electronics) for his technical support and advice with SAM, and Enago (www.enago.jp) for the English language review.

\section{Author Contributions}

KM designed the concept and wrote the manuscript. YF contributed to the cell culture and edited the manuscript. All authors have read and agreed to the published version of the manuscript.

\section{Institutional Review Board Statement}

The study was conducted according to the guidelines of the Declaration of Helsinki, and approved by the ethical committee of the Hamamatsu University School of Medicine (approval no. 19-180). Because the study used stored cytology samples without a link to the patient identity, the need for written consent was waived. All procedures were conducted according to the approved guidelines and regulations of the Ethics Committee.

\section{Data Availability}

The data presented in this study are available within the article figures and tables or supplementary materials.

\section{Conflicts of interest}

The author has nothing to disclose regarding conflicts of interest concerning this manuscript. 


\section{References}

1. Lemons R, Quate CF. Acoustic microscope - scanning version. Appl Phys Lett. 1974;24(4):163-5.

2. Scanning acoustic microscope [Internet]. [cited 2021 Jan 5]. Available from: https://en.wikipedia.org/wiki/Scanning_acoustic_microscope

3. Miura K. Atherosclerosis : Open Access Histological and Mechanical Information Based on Biochemical Alterations of Cardiovascular Diseases Using Scanning Acoustic Microscopy with Proteinases : A Novel Technique for Cardiovascular Research. 2021;6(2).

4. Saijo Y. Acoustic microscopy: latest developments and applications. Imaging Med [Internet]. 2009;1(1):47-63. Available from: http://search.proquest.com/docview/848413728?accountid=40046

5. Miura K. Application of Scanning Acoustic Microscopy to Pathological Diagnosis. In: Stanciu SG, editor. Microscopy and Analysis. Croatia: Intech; 2016. p. 381-403.

6. Miura K, Yamamoto S. A scanning acoustic microscope discriminates cancer cells in fluid. Sci Rep. 2015;5.

7. Miura K, Nasu H, Yamamoto S. Scanning acoustic microscopy for characterization of neoplastic and inflammatory lesions of lymph nodes. Sci Rep. 2013;3.

8. Miura K, Yamamoto S. Pulmonary imaging with a scanning acoustic microscope discriminates speed-of-sound and shows structural characteristics of disease. Lab Investig. 2012;92(12).

9. Miura K, Mineta H. Histological evaluation of thyroid lesions using a scanning acoustic microscope. Pathol Lab Med Int. 2014;6:1-9.

10. Miura K, Yamamoto S. Histological imaging of gastric tumors by scanning acoustic microscope. Br J Appl Sci Technol. 2014;4(1):1-17.

11. Miura K, Yamashita K. Evaluation of aging, diabetes mellitus, and skin wounds by scanning acoustic microscopy with protease digestion. Pathobiol Aging Age-related Dis. 2018;

12. Miura K, Yamashita K. Mechanical weakness of thoracic aorta related to aging or dissection predicted by speed of sound with collagenase. Ultrasound Med Biol. 2019;45(12):3102-15.

13. Miura K, Katoh H. Structural and histochemical alterations in the aortic valves of elderly patients: a comparative study of aortic stenosis, aortic regurgitation, and normal valves. Biomed Res Int. 2016;

14. Miura K. Tunica intima compensation for reduced stiffness of the tunica media in aging renal arteries as measured with scanning acoustic microscopy. PLoS One [Internet]. 2020;15(Nov 11). Available from: http://dx.doi.org/10.1371/journal.pone.0234759

15. Stokes's law of sound attenuation [Internet]. [cited 2021 Jan 4]. Available from: https://en.wikipedia.org/wiki/Stokes\%27s_law_of_sound_attenuation

16. Bereiter-Hahn J, Karl L, Luers H, Voth M. Mechanical basis of cell shape: investigations with the scanning acoustic microscope. Biochem Cell Biol. 1995;73:337-48.

17. Taggart LR, Baddour RE, Giles A, Czarnota GJ, Kolios MC. Ultrasonic characterization of whole cells and isolated nuclei. Ultrasound Med Biol. 2007;33(3):389-401.

18. Pasternak MM, Strohm EM, Berndl ESL, Kolios MC. Properties of cells through life and death - an acoustic microscopy investigation. Cell Cycle. 2015;14(18):2891-8.

19. Brand S, Weiss EC, Lemor RM, Kolios MC. High Frequency Ultrasound Tissue Characterization and Acoustic Microscopy of Intracellular Changes. Ultrasound Med Biol. 2008;34(9):1396-407.

20. Miura K, Yamamoto S. Histological imaging from speed-of-sound through tissues by scanning acoustic microscopy (SAM). Protoc Exch [Internet]. 2013; Available from:

https://protocols.scienceexchange.com/protocols/histological-imaging-from-speed-of-sound-through-tissues-by-scanningacoustic-microscopy-sam\%0D

21. M H Tan, N J Nowak, R Loor, H Ochi, A A Sandberg, C Lopez, J W Pickren, R Berjian, H O Douglass Jr TMC. Characterization of a New Primary Human Pancreatic Tumor Line. Cancer Invest. 1986;4(1):15-23.

22. Electron microprobe [Internet]. [cited 2021 Apr 4]. Available from: https://en.wikipedia.org/wiki/Electron_microprobe

23. Strohm EM, Czarnota GJ, Kolios MC. Quantitative measurements of apoptotic cell properties using acoustic microscopy. IEEE Trans Ultrason Ferroelectr Freq Control. 2010;57(10):2293-304.

24. Platinum-based antineoplastic [Internet]. [cited 2021 Feb 6]. Available from: https://en.wikipedia.org/wiki/Platinum-based_antineoplastic

25. Oxaliplatin [Internet]. [cited $2021 \mathrm{Feb} 6]$. Available from: https://en.wikipedia.org/wiki/Oxaliplatin

26. Denaturation (biochemistry) [Internet]. [cited 2021 Feb 5]. Available from: https://en.wikipedia.org/wiki/Denaturation_(biochemistry)\#Acids

27. Tannin [Internet]. [cited 2021 Feb 6]. Available from: https://en.wikipedia.org/wiki/Tannin

28. Chen WT, Sun YK, Lu CH, Chao CY. Thermal cycling as a novel thermal therapy to synergistically enhance the anticancer effect of propolis on PANC-1 cells. Int J Oncol. 2019;55(3):617-28.

29. Ethanol [Internet]. [cited 2021 Feb 6]. Available from: https://en.wikipedia.org/wiki/Ethanol\#Antidote 